\title{
Use of Mexican Propolis for the Topical Treatment of Dermatomycosis in Horses
}

\author{
Iris del Socorro Flores Rodríguez, Maxs Moreno Monteagudo, Amparo Londoño Orozco, \\ Tonatiuh Alejandro Cruz Sánchez \\ Facultad de Estudios Superiores Cuautitlán, Universidad Nacional Autónoma de México, Cuautitlán Izcalli, \\ México \\ Email: iflores@comunidad.unam.mx, tonatiuh86@hotmail.com
}

Received 6 November 2015; accepted 11 January 2016; published 14 January 2016

Copyright (C) 2016 by authors and Scientific Research Publishing Inc.

This work is licensed under the Creative Commons Attribution International License (CC BY). http://creativecommons.org/licenses/by/4.0/

(c) (i)

\section{Abstract}

Five horses with lesions compatible with dermatomycosis were selected and skin scrapings were taken from all affected areas. Samples were then treated with $10 \% \mathrm{KOH}$ and observed by direct microscopic examination; fungal cultures using Mycobiotic Agar and Borelli Agar were also preformed; Trichophyton mentagrophytes was identified in two cases, whereas Candida albicans was identified in the other three. Skin lesions in cases 1 and 2 were treated topically with ketoconazol ointment, while in the remaining cases a weekly bath with propolis-based shampoo and application of propolis-based ointment on the lesions 2 to 3 times a week were implemented. Treatment in all cases lasted 4 weeks. Pictures were taken before and after treatment and, making use of the Image Pro-Express ${ }^{\circledR}$ software, therapy efficacy was determined by measurement of lesion area diameter and a significant reduction in lesion size was observed by the end of the 4 weeks of treatment with ketoconazole and propolis-based products. Thus proving the effectiveness of such propolis-based products, making them a natural therapeutic alternative for the treatment of cutaneous mycoses in horses, and carrying none of the toxic side effects of conventional pharmaceuticals.

\section{Keywords}

Mexican Propolis, Horses, Dermatomycosis, Treatment

\section{Introduction}

Superficial and cutaneous mycoses are fungal infections that involve the superficial layers of the skin, hair, and claws/hoofs. The microorganisms involved are often keratinophilic dermatophytes, such as those belonging to 
the genus Microsporum, Trichophyton and Epidermophyton; however, other fungi like the yeasts Candida, Malassezia and Trichosporon may also produce superficial mycoses [1]. Cutaneous mycoses in horses are of great importance in veterinary medicine due to the zoonotic potential of most of the causative agents, the possibility of transmission between horses and to other species, the discomfort experienced by the infected animals, the aesthetic appearance of the skin, as well as the elevated costs of the pharmacological treatment [2], which tends to extend for long periods of time and can lead to possible side effects, not to mention the contraindications and resistance problems encountered with such treatments. For this reasons, in the last few years, there has been a growing interest in developing therapeutic compounds based on natural antimicrobial products that are easily applied and cheaper. Propolis is one of these products, a resin collected by bees and to which the presence of several compounds in its composition confers it with antibacterial, antiviral, fungicidal, anti-inflammatory, and immunomodulatory activities, all of which have been exhaustively investigated for years [3] [4]. Previous works have already demonstrated the benefits of the use of propolis for the treatment of cutaneous burn injuries in horses [5]. The purpose of this work is to provide a therapeutic alternative for the treatment of superficial mycoses which is practical and efficient, so that any patient can achieve full recovery with the use of a practical, economical and effective topical treatment that poses no risk to both, the patient and humans.

\section{Materials and Methods}

\subsection{Cases}

A total of 5 horses of both genders (Thoroughbred and American Quarter) were selected from different stables, ages ranging from 2 to 7 years, and weights between 430 and $540 \mathrm{~kg}$, each of them presented clinical signs compatible with cutaneous mycosis (annular areas of peripherally expanding alopecia, with or without erythematous borders, and fragile hair) but without any other apparent health alteration that could interfere with the results. The number and size of the lesions in each horse, as well as their distribution, was recorded in a work sheet that depicted the anatomical regions of the horse; such evaluation was made before and after treatment. Case 1: American Quarter horse, 5 years old, sorrel. Showed a large alopecic region that covered the caudal aspect of the head, from the ear base to the bottom of the jaw, and another small alopecic lesion on the temple, both on the right side on the face (Figure 1(a)). Each horse was privately owned and thus welfare concerns were directly supervised by staff members of a given stable, which was different for each horse.

Case 2: American Quarter mare, 7 years of age, light sorrel. Showed multiple annular alopecic lesions on the lacrimal, zygomatic, and maxillary bone regions, on the right and left side of the face (Figure 2(a) and Figure 2(c)).

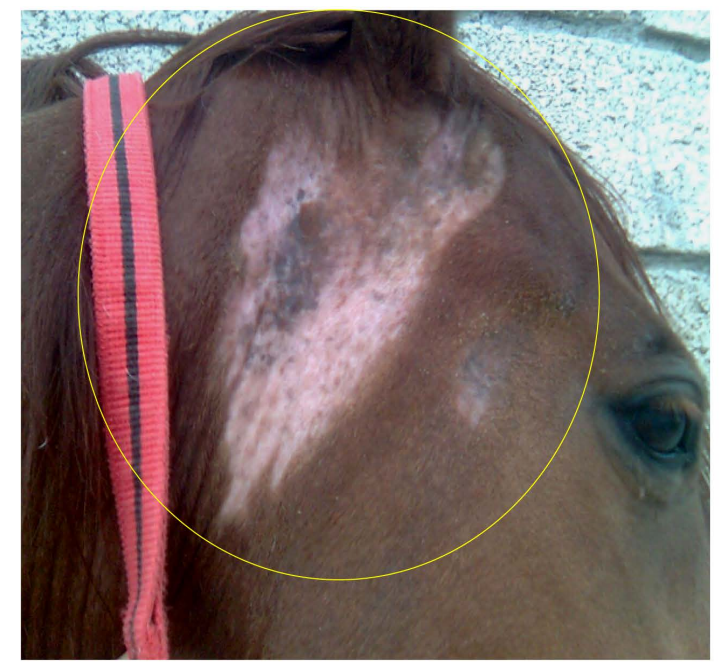

(a)

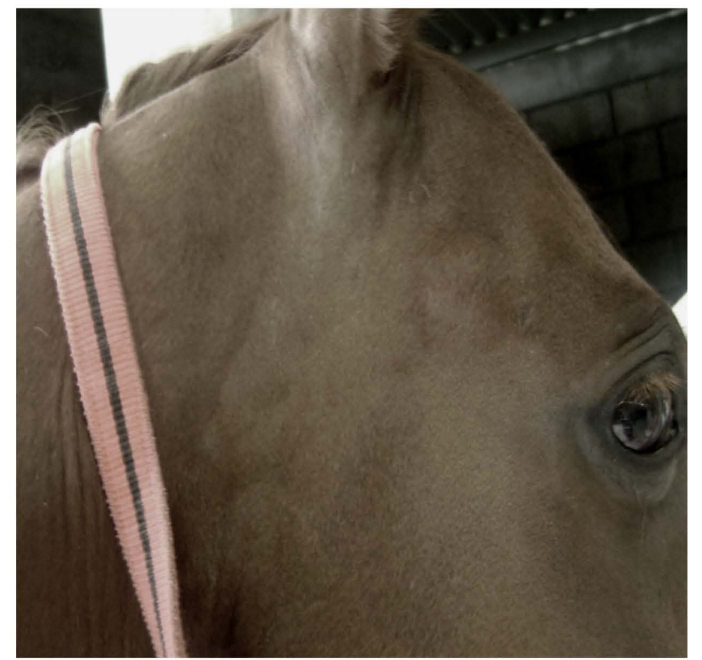

(b)

Figure 1. Case 1: Horse, American Quarter. (a) Lesion caused by Trichophyton mentagrophytes on the caudal aspect of the head, from the ear base to the bottom of the jaw, and another small alopecic lesion on the temple, both on the right side; (b) Same areas after 4 weeks of ketoconazole ointment treatment. 


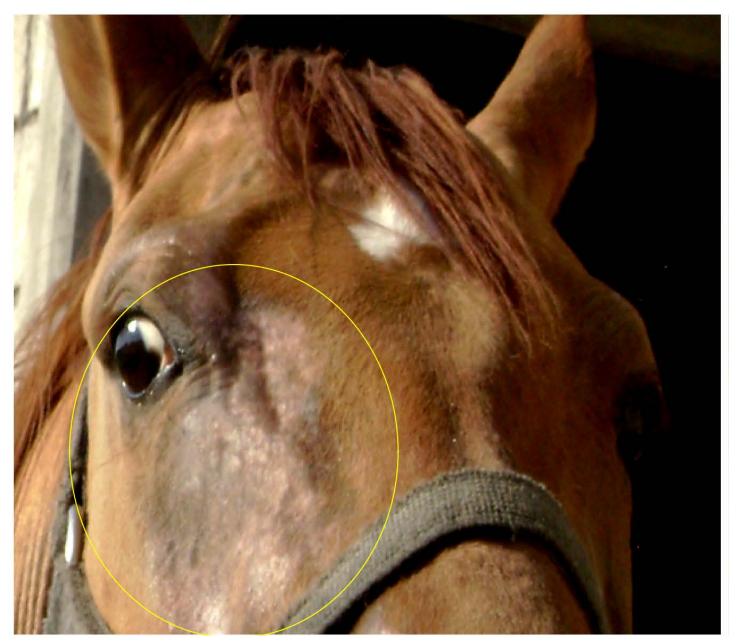

(a)

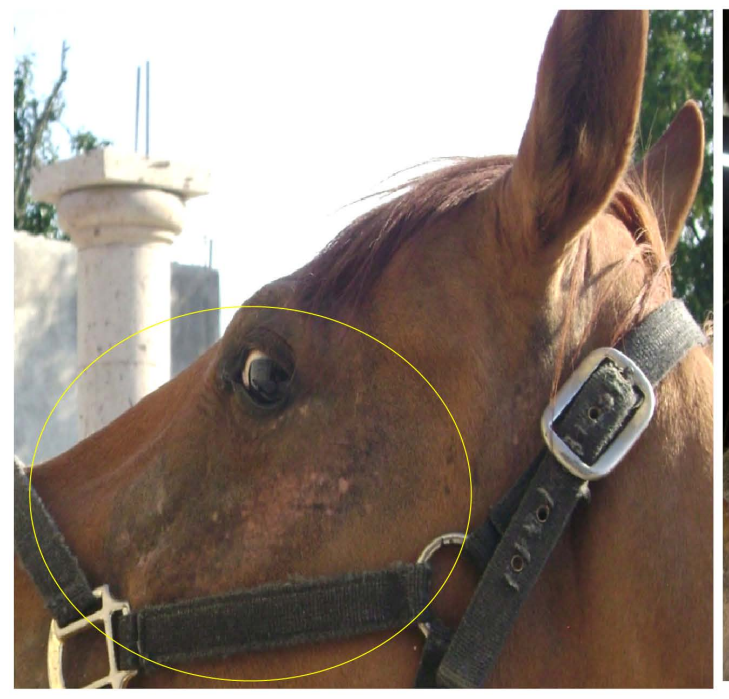

(c)

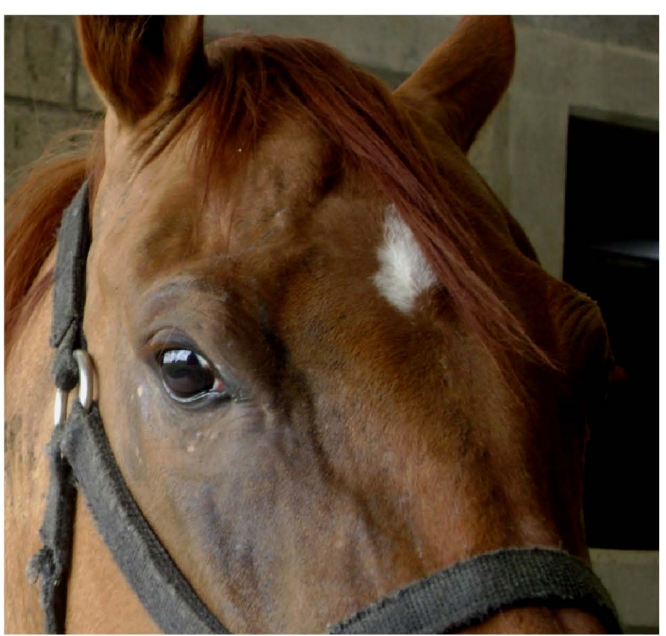

(b)

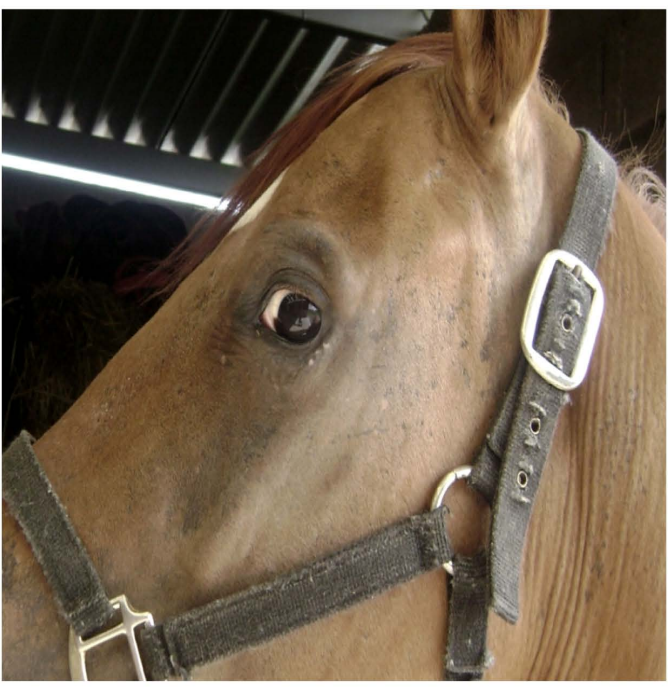

(d)

Figure 2. Case 2: Mare, American Quarter. Lesions caused by Candida albicans. (a) Right side, treated with ketoconazole ointment; (b) Same area after 4 weeks of treatment; (c) Left side, treated with propolis-based shampoo and ointment; (d) Same area after 4 weeks of treatment.

Case 3: Thoroughbred filly, 2 years of age, dark bay. Showed multiple annular alopecic lesions on the craneoventral part of the barrel (Figure 3(a)).

Case 4: Thoroughbred colt, 2 years of age, brown. Showed multiple annular alopecic on the breast (Figure 4(a)).

Case 5: Thoroughbred filly, 2 years of age, brown. Presented several annular alopecic lesionson the girth, of approximately $2 \mathrm{~cm}$ in diameter each (Figure 5(a)).

\subsection{Laboratory Procedures}

For each mycological examination, hair samples were taken and scales were collected from the edges of thelesions for direct microscopic examination with $10 \% \mathrm{KOH}$. These samples were then used to inoculate plates containing Mycobiotic Agar $\left(\operatorname{Bioxon}^{\circledR}\right)$ and Borelli Agar [6]. After that, Petri dishes were incubated at $28^{\circ} \mathrm{C}$ for one week, by the end of which we were able to observe the formation of growing colonies. Using Riddel's microculture technique, identification was performed based on the morphological characteristics, using the monographs of Larone [7]. In order to observe yeast-like structures, Gram stains were performed to those colonies 


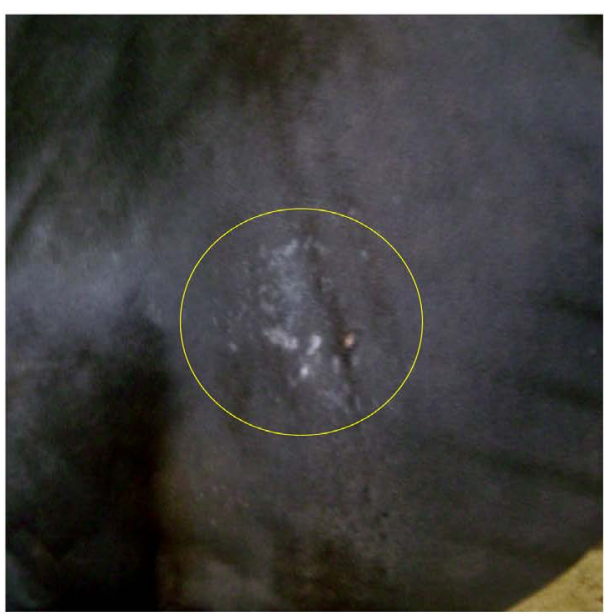

(a)

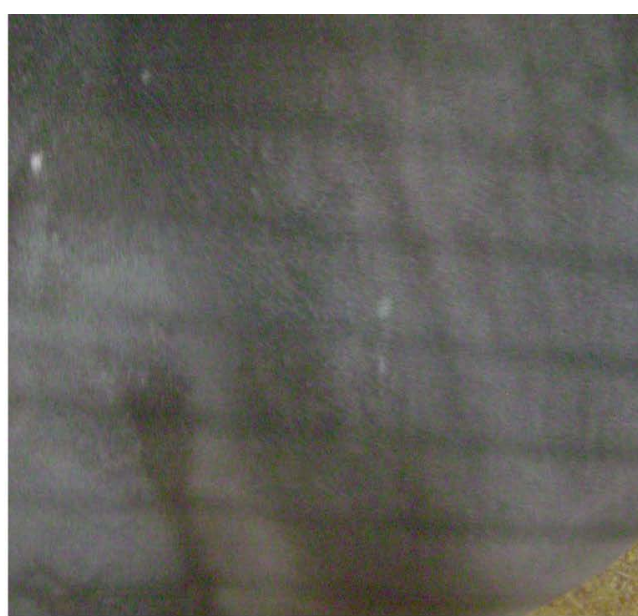

(b)

Figure 3. Case 3: Filly, Thoroughbred. Skin infection caused by Candida albicans on the craneoventral part of the barrel. (a) Annular alopecic lesions; (b) Same area after 4 weeks of propolis-based shampoo and ointment.

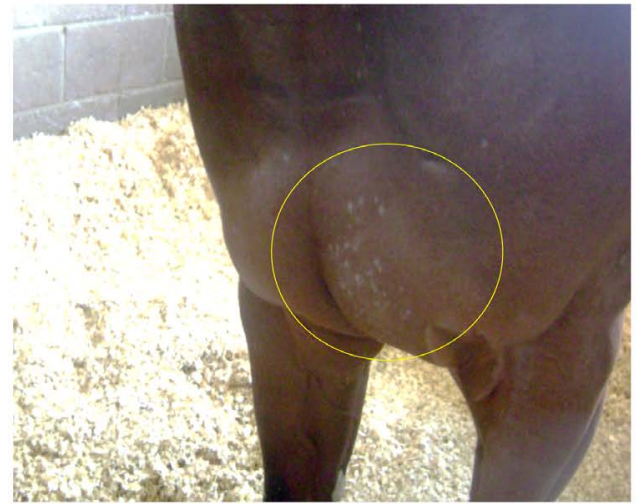

(a)

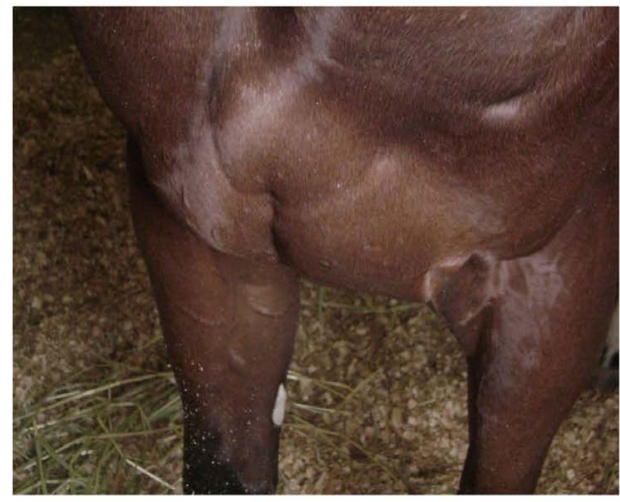

(b)

Figure 4. Case 4: Colt, Thoroughbred. (a) Skin lesions caused by Candida albicans on the left side of the breast; (b) Same area after 4 weeks of propolis-based treatment.

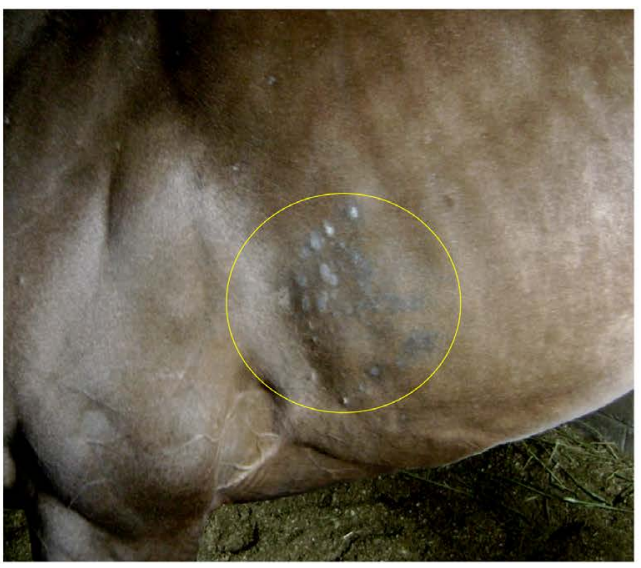

(a)

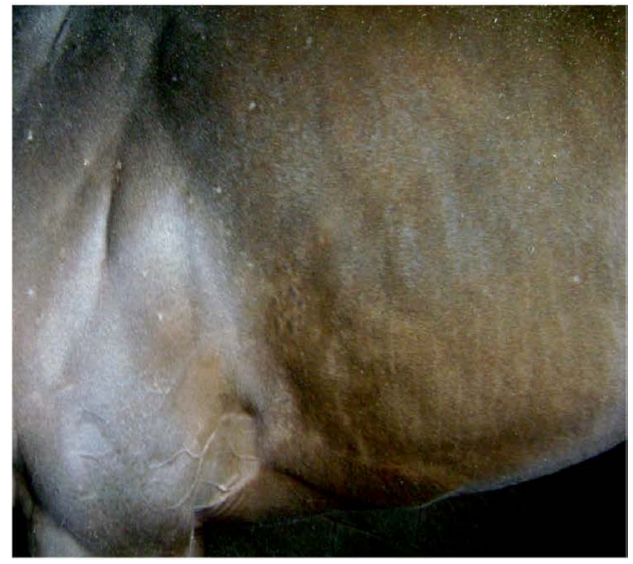

(b)

Figure 5. Case 5: Filly, Thoroughbred. (a) Annular alopecic lesions on the girth caused by Trichophyton mentagrophytes; (b) Same area after 4 weeks of propolis-based treatment. 
whose whitish, creamy appearance corresponded to that observed in Candida spp. cultures. A germ tube test, also known asmycelial growth test, was then performed in order to identify the species [8].

\subsection{Treatment}

In case 1, ketoconazole ointment (Nizoral, Janssen-Cilag ${ }^{\circledR}$ ) was applied on the affected areas; In case 2, ketoconazole ointment was also applied, but only on the lesions on the right side of the face, whereas propolis-based products were used to topically treat the lesions on the left side. The three remaining cases were only treated with propolis-based compounds, a weekly bath was given with propolis-based shampoo (consisting of both, oily- and soapy-phases, excipients and $3 \%$ propolis) and $15 \%$ propolis ointment (the composition of which was taken from a previous publication by Cruz [9]) was applied on the lesions 2 to 3 time a week. Treatment in all cases lasted 4 weeks. Propolis' active substances were determined by HPLC analisis, the most relevant being flavones, cinnamic acid and caffeic acid [10]. Both propolis-based products were supplied by the Multidisciplinary Research Unit of the FES-Cuautitlán, UNAM.

\subsection{Evaluation and Statistic Analysis}

Photographs of the lesions were taken before and after treatment; the pictures were then analyzed with the Image-Pro Express 4.5 software and data corresponding to lesion size changes and distribution were recorded. After that, an ANOVA test (GraphPad Prism software) of the data corresponding to the size of the lesions before and after treatment was carried out and a $p$ value $<0.005$ was obtained, so that a statistically significant reduction in lesion size was confirmed.

\section{Results}

Samples were treated with $10 \% \mathrm{KOH}$ and a direct microscopic examination was performed. In cases 1 and 5 , ectothrix parasitism of hair shafts was observed and, in both cases, the dermatophyte Trichophyton mentagrophytes was isolated, whereas in the remaining cases (2, 3, and 4) the yeast Candida albicans was identified.

By the end of the 4 weeks of treatment it was evident that the skin lesions of the horses treated with propolisbased shampoo and ointment showed a reduction in the size of the area involved, thus resulting in lesion size reduction of statistical significance. No recidivism of the lesions was observed in any case (Table 1; Figure 1(b), Figure 2(b), Figure 2(d), Figure 3(b), Figure 4(b) and Figure 5(b)).

\section{Discussion}

Previous works have already shown the antifungal activity of propolis against dermatophytesin dogs, cows and rabbits [4] [11]; also, its in vitro activity against Trichophyton mentagrophytes has been noted in several studies [12]. Furthermore, the present work not only succeed in demonstrating the effectiveness of propolis for the treatment of dermatophytosis in horses caused by Trichophyton, but also proved its viability as an effective treatment for skin infections caused by Candida albicans.

Table 1. Summary of results obtained in horses topically treated with ketoconazole and propolis*.

\begin{tabular}{|c|c|c|c|c|c|c|c|c|}
\hline Case & Breed & Age (years) & Gender & $\begin{array}{c}\text { Isolated } \\
\text { microorganism }\end{array}$ & Treatment & $\begin{array}{l}\text { Area before } \\
(\mathrm{cm})\end{array}$ & $\begin{array}{l}\text { Area after } \\
(\mathrm{cm})\end{array}$ & $\begin{array}{c}\text { Lesion } \\
\text { reduction (\%) }\end{array}$ \\
\hline 1 & $\begin{array}{l}\text { American } \\
\text { Quarter }\end{array}$ & 5 & Male & $\begin{array}{l}\text { Trichophyton } \\
\text { mentagrophytes }\end{array}$ & Ketoconazole & 55.27 & 2.44 & 95.58 \\
\hline 2 & $\begin{array}{l}\text { American } \\
\text { Quarter }\end{array}$ & 7 & Female & $\begin{array}{l}\text { Candida } \\
\text { albicans }\end{array}$ & $\begin{array}{l}\text { Ketoconazole(rs) } \\
\text { Propolis(ls) }\end{array}$ & $\begin{array}{c}86.15 \\
31.9\end{array}$ & $\begin{array}{l}0.24 \\
0.16\end{array}$ & $\begin{array}{l}99.72 \\
99.50\end{array}$ \\
\hline 3 & Thoroughbred & 2 & Female & $\begin{array}{l}\text { Candida } \\
\text { albicans }\end{array}$ & Propolis & 55.61 & 0.58 & 98.95 \\
\hline 4 & Thoroughbred & 2 & Male & $\begin{array}{l}\text { Candida } \\
\text { albicans }\end{array}$ & Propolis & 20.01 & 0.60 & 97.05 \\
\hline 5 & Thoroughbred & 2 & Female & $\begin{array}{l}\text { Trichophyton } \\
\text { mentagrophytes }\end{array}$ & Propolis & 20.17 & 0.30 & 98.51 \\
\hline
\end{tabular}

${ }^{*} p=0.005 ;$ rs $=$ right side; ls $=$ left side. 
The effectiveness of propolis for the treatment of C. albicans in horses is probably due to its ability to inhibit yeast growth, blastoconidia formation and germ tube formation (an important virulence factor of C. albicans), as well as its damaging effect on cell membrane and wall. Such damages have also been reported by [13], who demonstrated that, in vitro, a propolis concentration of $0.3 \mathrm{mg} / \mathrm{ml}$ is capable of inhibiting yeast growth and blastoconidia formation (yielding the microorganism incapable of reproducing), and creates morphological alterations by means of cellular membrane and wall damage, and even nuclear membrane damage.

A synergic effect with the combined use of propolis-based shampoo and oitment was also observed. Tensoactive activity is provided by several components of the shampoo (sodium lauryl sulfate, amines, sugar alcohols, cocamidopropyl betaine), which eliminate sweat, ceruminous secretions, dead cells, and dirt form the environment, as mentioned by [14]. Once these substances have been removed from the skin's surface, a better residual activity from the propolis contained in the ointment is achieved. A similar study on dermatophytosis in cows was conducted by [11], wherein he mentions that better results are obtained when the application of propolis-based ointment is combined with the application of another oitment that contains benzoic and salicylic acids, instead of using one product alone.

In the present study, topical treatment protocols were implemented for a period of 4 weeks, which has relevance when dealing with extensive skin lesions and correlates with a study in dogs by [9], were patient treatment consisted of a daily wash of the lesions with any commercially available propolis-based soap, followed by the application of a propolis-based ointment; horses were checked every 7 days and complete remission of the lesions and hair growth in affected areas were achieved by the third week of treatment, as well as an overall reduction of pruritus caused by secondary bacterial infection, and increased patient acceptance of treatment application.

The regenerative and wound healing capacities of propolis on skin lesions in horses were also observed in this study, as was proven by size reduction of annular alopecic areas, which was also demonstrated by Howaida et al. [5], who evaluated the efficacy of propolis to enhance skin regeneration of old and recent lesions. On the other hand, the work here presented also succeed in demonstrating resolution of skin lesions in horses caused by both, dermatophytes and yeast, after the topical application of propolis-based products, which in turn is associated with the antimicrobial properties of the resin, the presence of free radicals and metabolism stimulation, which speeds up tissue regeneration [15]-[17].

The presence of substances such as caffeic acid (present in our propolis) and kaempferol could also play an important role in tissue regeneration. These substances induce the anagen phase of the hair cycle, as demonstrated by Miyata et al. [18], who conducted an investigation in which dilutedethanol-extracted propolis was topically applied to mice that had been previously shaved or wax depilated. Their results showed that the subjects that had received topical treatment with propolis recovered their hair coat faster than those who had not received such treatment, due to the fact that anagen phase induction occurred without any detectable anomalies in hair follicle conformation when this treatment was implemented. The same authors also observed that, after the topical application of the product, the number of cells associated with hair growth increased and keratinocyte proliferation was stimulated.

Regarding case number 2, were the lesions on the right side of the face were treated with ketoconazole ointment, the presence of a mild hyperpigmentation of the area was observed after the resolution of the lesions, which did not happen on the left side, where instead propolis-based products were used, nor did it happen in case 1, where ketoconazole ointment alone was used. Such secondary effect of ketoconazole has not been documented, which lead the authors to consider it an isolated reaction.

The results here presented are non-conclusive, given the small amount of treated animals; however they do provide some guidance for further research on the subject. An important aspect worth of mentioning is that relating to treatment cost per animal, which was of approximately $\$ 100$ (USD) for the whole treatment with ketoconazole ointment, and of approximately $\$ 30$ (USD) when propolis-based products were used, hence, a significant reduction in treatment cost can be appreciated without compromising the outcome in lesion size reduction, which is similar with both treatments

These research paper adds up to the ever growing scientific literature that present the use of propolis as an attractive alternative therapeutic agent against fungal skin infections that can be safely employed in pediatric, geriatric and pregnant patients, and even in those with renal and/ or hepatic failure, which constitutes a significant advantage over treatments with conventional pharmaceuticals, that while is true are effective, their use is limited in the treatment of such patients, due to their hepatotoxic, embryotoxic and teratogenic effects, as well as many drug interactions [19] and [20]. 


\section{Conclusion}

After a thorough review of the currentscientific literature available on the subject, not a single paper about the use of propolis for the treatment of dermatomycosis in horses was found, so it is possible that this work constitutes the first written scientific report of the application of propolis for the treatment of dermatomycosis in this species.

\section{Acknowledgements}

The authors would like to express their gratitude to the UNAM DGAPA projects PAPIIT IT 223811-3 and IT 200915, PIAPIC 28C and support by CONACYT 713123.

\section{References}

[1] Scott, D.W. and Miller, W.H. (2010) Equine Dermatology. 2nd Edition, W. B. Saunders, Philadelphia, 231-232.

[2] Pérez, J. and Carrasco, L. (2000) Histopatological Diagnosis of Mycoses in Veterinary Pathology. Revista Iberoamericana de Micología, 17, 18-22.

http://www.researchgate.net/profile/Jose_Perez23/publication/238770693_Diagnstico_histopatolgico_de_micosis_en patologa_veterinaria/links/53d8a4ca0cf2a19eee8358b4.pdf

[3] De Castro, S.L. (2001) Propolis: Biological and Pharmacological Activities. Therapeutic Uses of This Bee-Product. ARBS Annual Review of Biomedical Sciences, 3, 49-83. http://132.248.9.34/hevila/ARBSAnnualreviewofbiomedicalsciences/2001/vol3/2.pdf

[4] Bogdanov, S. (2014) Propolis: Composition, Health, Medicine: A Review. Bee Product Science, 1-40. http://www.bee-hexagon.net/files/file/fileE/Health/PropolisBookReview.pdf

[5] Howaida, A.A. and Abdel, R.E. (2013) Evaluation of the Effectiveness of Propolis Compared with Honey on Second Intention Wound Healing in the Equine. Middle-East Journal of Science Research, 14, 1292-1298. http://www.idosi.org/mejsr/mejsr14\%2810\%2913/6.pdf

[6] Bonifaz, A. (2012) Micología Médica Básica. 4th Edition, Editorial McGraw Hill, México, 61-97.

[7] Larone, D.H. (2011) Medically Important Fungi: A Guide to Identification. 5th Edition. ASM Press, Washington DC.

[8] Elmer, W., Koneman, E.W. and Allen, S. (2005) Microbiological Diagnosis: Text and Color. Médica Panamericana. 6th Edition, Buenos Aires, 1164-1668.

[9] Cruz Sánchez, T.A., Estrada García, P.A., López Zamora, C.I., Autran Martínez, M., Pérez Valencia, V. and Londoño Orozco, A. (2014) Use of Propolis for Topical Treatment of Dermatophytosis in Dog. Open Journal of Veterinary Medicine, 4, 239-245. http://dx.doi.org/10.4236/ojvm.2014.410028

[10] Londoño, A., Canales, M., Hernandez, T., Ávila, G., Serrano, R., Penieres, J., García, C., Cruz, T., et al. (2010) Antibacterial Comparative Study between Extracts of Mexican Propolis and of Three Plants Which Use Apis mellifera for Its Production. Journal of Animal and Veterinary Advances, 9, 1250-1254. http://dx.doi.org/10.3923/javaa.2010.1250.1254

[11] Cam, Y., Koç, A.N., Silici, S., Günes, V., Buldu, H., Onmaz, A.C. and Kasap, F.F. (2009) Treatment of Dermatophytosis in Young Cattle with Propolis and Whitfield's Ointment. Veterinary Record, 165, 57-58. http://www.researchgate.net/publication/26665383_Treatment_of_dermatophytosis_in_young_cattle_with_propolis_an d_Whitfield\%27s_ointment http://dx.doi.org/10.1136/vetrec.165.2.57

[12] Koc, S., Silici, D., Ayangil, A. and Ferahbas, S. (2005) Comparison of in Vitro Activities of Antifungal Drugs and Ethanolic Extract of Propolis against Trichophyton rubrum and T. mentagrophytes by Using a Microdilution Assay. Mycoses, 48, 205-210. http://onlinelibrary.wiley.com/doi/10.1111/j.1439-0507.2005.01128.x/full http://dx.doi.org/10.1111/j.1439-0507.2005.01128.x

[13] Londoño, A., Penieres, J., García, C., Carrillo, L., Quintero, M., García, S., Mendoza, M. and Cruz, T.A. (2008) Estudio de la actividad antifúngica de un extracto de propóleo de la abeja Apis mellifera proveniente del estado de México. Tecnología en Marcha, 21-1, 49-55.

[14] Chavez, J.G. (2013) Elaboración de Shampoo de romero (Rosmarinum officinalis) con actividad anti Malassezia globosa a escala piloto. Escuela Superior Politécnica de Chimborazo, Fac. de Ciencias, Escuela de bioquímica y Farmacia, Ribomba. http://dspace.espoch.edu.ec/bitstream/123456789/2558/1/56T00325.pdf

[15] Castaldo, S. and Carpasso, F. (2002) Propolis, an Old Remedy Used in Modern Medicine. Fitoterapia, 73, 1-6. http://www.sciencedirect.com/science/article/pii/S0367326X02001855 http://dx.doi.org/10.1016/S0367-326X(02)00185-5 
[16] Burdock, G.A. (1998) Review of the Biological Properties and Toxicity of Bee Propolis (Propolis). Food and Chemical Toxicology, 36, 347-363. http://www.sciencedirect.com/science/article/pii/S0278691597001452 http://dx.doi.org/10.1016/S0278-6915(97)00145-2

[17] Marcucci, M.C. (1995) Propolis: Chemical Composition, Biological Properties and Therapeutic Activity. Apidologie, 26, 83-99. https://hal.inria.fr/file/index/docid/891249/filename/hal-00891249.pdf http://dx.doi.org/10.1051/apido:19950202

[18] Miyata, S. and Matsuo, S. (2004) Stimulatory Effect of Brazilian Propolis on Hair Growth through Proliferation of Keratinocytes in Mice. Journal of Agricultural and Food Chemistry, 62, 11854-11861. http://pubs.acs.org/doi/pdf/10.1021/jf503184s http://dx.doi.org/10.1021/jf503184s

[19] Kaur, R., Kashyap, B. and Bhalla, P. (2008) Onychomycosis-Epidemiology, Diagnosis and Management. Indian Journal of Medical Microbiology, 26, 108-116. http://www.bioline.org.br/pdf?mb08035

[20] Rivas, G. and Cardona, N. (2009) Systemic Antifungals: Which Therapeutic Options Do We Have? CES Medicina, 23, 61-76. http://www.scielo.org.co/scielo.php?pid=S0120-87052009000100007\&script=sci_arttext 